\title{
CLASS-BASED SOCIAL NETWORKS IN REGIONAL ECONOMIC SYSTEMS
}

By: Eric C. Jones

2003 E.C. Jones. Class-Based Social Networks in Regional Economic Systems. Research in Economic Anthropology 22:3-23.

Made available courtesy of Elsevier: http://www.sciencedirect.com/science/bookseries/01901281

***Note: Figures may be missing from this format of the document

\begin{abstract}
:
Does a village's location in a regional economic system predict the extent to which close interpersonal relationships are based on socioeconomic similarity? A comparison of sample social networks of four frontier villages in northwest Ecuador showed that village centrality influences the dominant types of social relationships and, thus, the differential tendencies for socioeconomic differentiation. Compared to residents in peripheral villages, those in central ones were more likely to name individuals of their own class and to note mutual relations in their social networks.
\end{abstract}

\section{Article:}

INTRODUCTION

Analyses of regional economic systems have made great headway in predicting human economic and social behavior based on the ease of access to a place or its distance from an economic center. Although archeologists have been foremost in their use of this theoretical framework, researchers interested in contemporary populations have also made contributions. However, studies are scarce that consider interpersonal relations within regional systems. Besides those relations that can be characterized as market-based exchange, the studies on social relations in Carol Smith's volumes focus mainly on marriage and kinship (1976a, b). Exceptions are Beck (1976) who found caste relations to follow patterns predicted by location in a regional system, and Smith (1976d) who created a typology of regional systems by considering the influence of class structure. The current study builds upon such work by exploring the extent to which interpersonal relationships within villages are based on socioeconomic similarity as predicted by the villages' location in a regional economic system.

A pioneer colonization zone in northwestern Ecuador was the study site of four villages. Such a frontier situation is ideal for the study of the development of social organization. The frontier has proved theoretically alluring to social scientists at least since the formulation of Frederick Jackson Turner's "Frontier Thesis" concerned with the democratizing force of the North American West (Turner, 1961). However, virtually unnoticed have been calls to study socio-cultural change in pioneer communities in order ". . . to specify precisely what is changing, from what and to what" (Thompson, 1973, p. 3). Besides examining the influence of location in a regional system on social networks, this analysis offers a glimpse into how socioeconomic criteria for relationships might change in a village over time.

\section{CENTRAL PLACE THEORY}


The Las Golondrinas frontier area of northwestern Ecuador is a dendritic system - a type of regional economic system having a single town as the only way out of a region - from which smaller towns, and then villages, and then rural areas spread out (see Fig. 1). Central place theory holds that variation in economic and social activities can be observed along a gradient, radiating out from a larger, more influential central town. This prediction is based originally on von Thünen's idea that intensiveness of land use around an urban center will vary directly with proximity to the urban center (Hall, 1966). Analyzing the relationship between consumers and suppliers, Christaller (1966) presented a nested pattern of central places, showing how the center has high- and low-order goods, while the outlying areas have only low-order goods. Smith concluded in a review of regional analyses that the presence or absence of goods is reliably predicted by location in a central place system (1976c, p. 15).

A regional focus on export monoculture - like the early specialization of Las Golondrinas on coffee and cacao, as well as its current focus on palm and rice - tends to create a dendritic system, which is characterized by external demand, foreign capital, interregional transport, hierarchy of commercial centers, and local organization of productive sectors (Appleby, 1976, p. 292). The producers furthest from the core typically have access to less information about prices, plus have less access to transportation, putting them at the vagaries of unstable markets. To limit competition between themselves in the core of such a regional system, middlemen

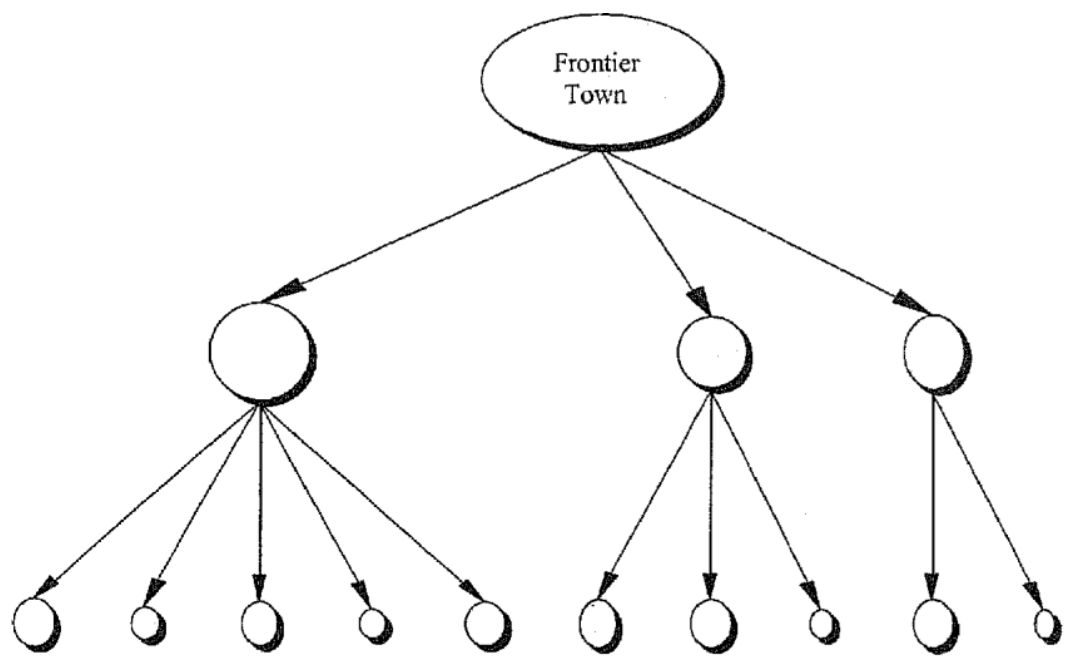

Fig. 1. Idealized Dendritic Regional Economic System.

sometimes reduce producer prices when they have more price information than do the producers, use bad weights on scales, impose excessive discounts for dirt and moisture in grains, and use "company store" type practices. All of these methods hurt the producer (ibid., pp. 302-303).

What about the variation between places in a regional system at a finer level of social organization, such as at the level of social networks? Although there has been little work done on social networks based on central place theory, there are some indications that such networks vary with location in a regional economic system. For example, peasants are more likely to trust others interpersonally but less politically, while urbanites have the opposite tendency. This may be due to the fact that lack of government support has led peasants to become more dependent on community-based efforts than 
urban residents (Seligson \& Salazar, 1979, p. 519). Also, peasants in frontier zones have been characterized as conservative individualists (Thompson, 1973).

Smith's characterization of peasant culture focused on the case of a regional economic system, a brief description of which is in order (1976d, p. 352). The lack of contact between the pioneer peasants at the periphery and elites in the urban areas in a regional economic system means that the core culture may have little effect on peasant culture. For this reason, peasants and farm laborers are considered traditional and unchanging. Nonetheless, both peasants in the larger villages and more successful peasants identify with elites of more powerful urban areas, and this is obvious to poorer and isolated peasants. Moreover, peasants can change classes and ethnicity by changing residence through migration or by becoming merchant-traders. ${ }^{1}$ As a result — according to Smith — classconsciousness does not necessarily arise among peasants.

Smith's findings show that even if a non-conformist shows up on the frontier - a place of instability and change - little contact with the outside makes the pioneer an unlikely purveyor of progress over the long term. Therefore, in addition to resulting from risk minimization (cf. Smith, 1988), peasant conservatism accompanies predictable variation in status and trust as potential products of a regional system's structure. The specific question addressed below is whether the more central villages of a rural, dendritic central place system exhibit local social relations in which people develop affinity for people belonging to their own class. The corollary would be that a myriad of interpersonal relationships based on trust, charisma, family, religion, political identity, proximity, and so on are typical in the more peripheral rural settings where they overshadow shared class as a basis for strong relationships.

\section{ETHNOGRAPHIC BACKGROUND OF SAMPLE VILLAGES}

Table 1 presents the general history of development and important town characteristics of the four villages selected in the Las Golondrinas colonization zone in northwest Ecuador. Besides providing some ethnographic context, the data indicate the appropriate position of each village in the dendritic central place system. The area was colonized first in the 1970s by smallholder farm families who primarily cultivated coffee and cacao. People seeking smallholdings continue to trickle in, but younger laborers on African palm and palmito (palm hearts) plantations have fueled most of the inmigration recently. Both landed and laboring peasants arrived primarily from the coastal areas, as Fig. 2 depicts. As of 1997, only half of the residents of the Las Golondrinas area owned land, and absentee landlords were estimated to own around half of the area's land (Jones, 2002, pp. 26-27).

La Te is connected to more roads than the three other villages. It is also accessed by more buses and cars, and has a relatively large population. La Te lies on the road to Zapallo, while El Recreo and Diez de Agosto are accessed by other roads from the town of Las Golondrinas. The population of La Te is 972, that of Zapallo is 1,080, that of El Recreo is 341, and that of Diez de Agosto is 270. (Table 1 presents estimates of village populations based on a 1997 migration survey summarized in Jones (2002).)

In order of importance in the dendritic regional economic system connected to the frontier town of Las Golondrinas, it is obvious that La Te is much more of a 
Table 1. Characteristics of Four Villages in the Study.

\begin{tabular}{|c|c|c|c|c|c|c|c|c|}
\hline Village & $\begin{array}{l}\text { Year of } \\
\text { Origin }\end{array}$ & $\begin{array}{c}\mathrm{km} \text { to } \\
\mathrm{LG}\end{array}$ & $\begin{array}{l}\text { Estimated No. } \\
\text { of Households } \\
\text { \& People }\end{array}$ & $\begin{array}{l}\text { Buses } \\
\text { per Day }\end{array}$ & $\begin{array}{l}\text { Road from } \\
\text { LG Since }\end{array}$ & $\begin{array}{c}\text { No. of } \\
\text { Road Links }\end{array}$ & $\begin{array}{l}\text { No. of Autos } \\
\text { in Town }\end{array}$ & $\begin{array}{c}\text { Average } \\
\text { Years }^{\mathrm{b}} \text { of } \\
\text { Residence }\end{array}$ \\
\hline $\mathrm{LaTe}$ & 1977 & 13 & $180(972)$ & 12 & 1981 & 3 & Many & 11 \\
\hline Zapallo & 1974 & 22 & $200(1080)$ & 8 & 1981 & 3 & 10 & 15 \\
\hline El Recreo & 1970 & 15 & $55(341)$ & 2 & 1989 & 2 & 8 & 21 \\
\hline Diez de Agosto & 1980 & 10 & $50(270)$ & 2 & 1990 & 2 & 2 & 12 \\
\hline
\end{tabular}

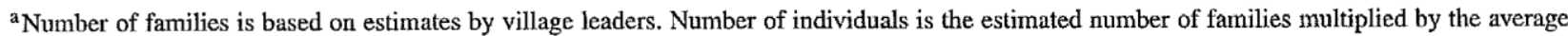
household size in each village, based on a SANREM Migration Survey which provided a random sample of households in the village and surrounding area (La Te $n=42$, Zapallo $n=27$, El Recreo $n=25$, Diez de Agosto $n=12$ ). All but El Recreo averaged 5.4, and El Recreo averaged 6.2 persons per household.

' In no case is the median length of interviewees' residence more than one year different than the average.

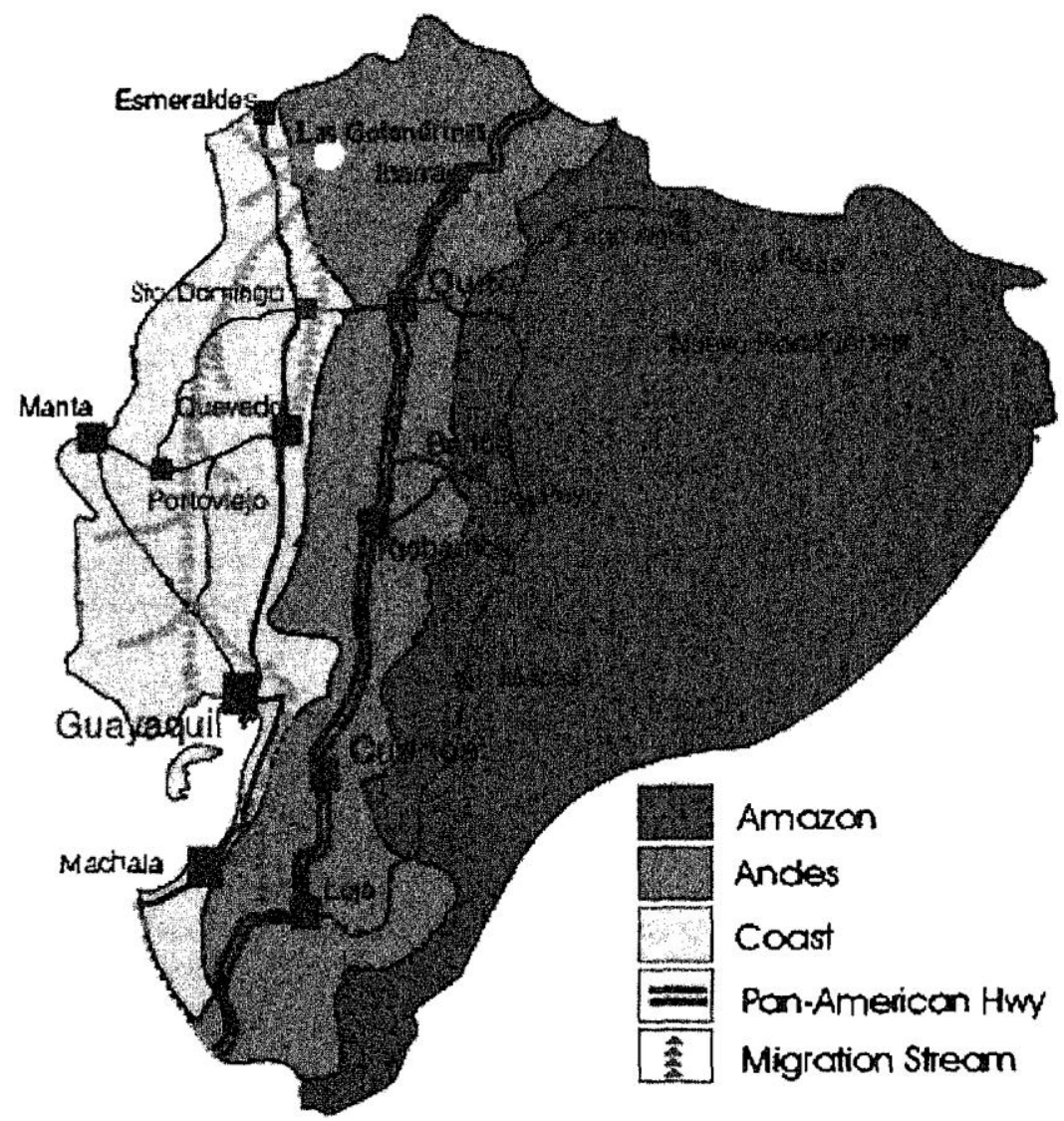

Fig. 2. Origin of Las Golondrinas In-Migration, in Relation to Ecuador's Ecological Zones. 
central place than the other three. Next is Zapallo, then El Recreo, and then Diez de Agosto based on the amount and kinds of contact these villages have with the town of Las Golondrinas.

Of the four villages in the sample, La Te lies closest to Las Golondrinas (see Fig. 3), and contains more services than the other communities. Buses travel to La Te several times a day. Furthermore, the village has been organized according to a relatively formal street grid. Settled later than Zapallo, La Te also was populated first from the west through Cole and the Canandé River, and not through Las Golondrinas. Cole, which lies 25 kilometers northwest of Zapallo on the Canadé River, now is accessed by bus and car on a different road from Quinindé than is

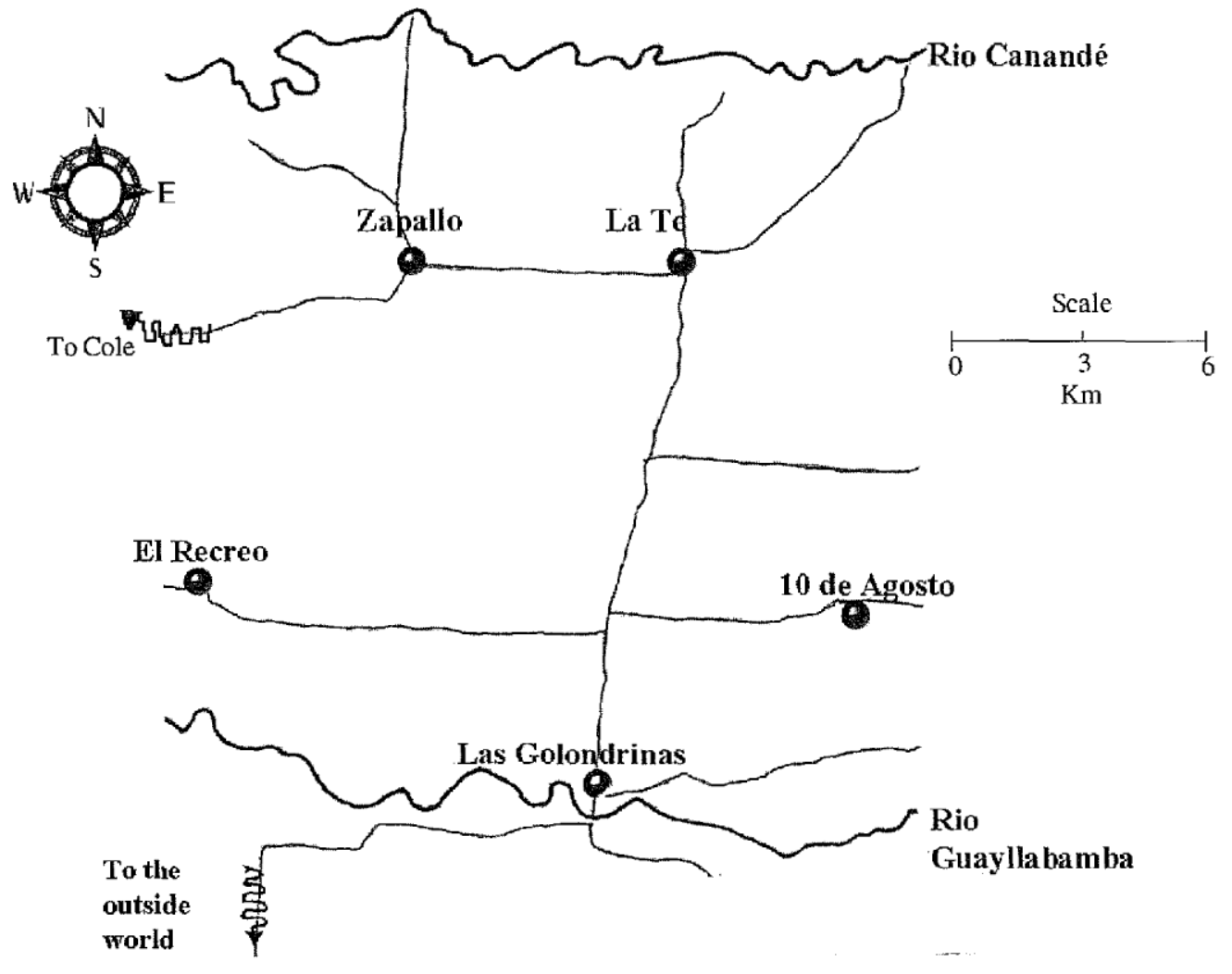

Fig. 3. Geographical Relationship of Study Villages to Town of Las Golondrinas.

Las Golondrinas, and Cole is rarely visited by any other people in the region shown in Fig. 3. Las Golondrinas now provides the only outlet from the dendritic region plus the four villages in the study are peripheral only to Las Golondrinas. ${ }^{2}$

Zapallo boasts the largest population of the four villages, with 200 families in the village proper and 100 additional families in its immediate surroundings. Within this larger Zapallo area, 10 families have vehicles, half of which are pick-ups and the rest are grain trucks. Zapallo had a slightly less contentious relationship than did La Te with the lumber company that had possessed governmental logging concessions in the area during the village's formation. Zapallo's original settlement occurred together with logging operations that entered through Cole farther west on the Canandè River. 
El Recreo village is the oldest in the sample and was populated by way of a river crossing farther west from Las Golondrinas. The village lacks the typical overarching political institution such as village council (comité de promejoras), but has an all-male committee responsible for electricity and roads, plus an all-female provivienda committee involved in general village welfare and social activities. In addition, a parent-teacher association has been established at the school. There are seven cars/pickups and one farm truck in El Recreo.

Diez de Agosto is the youngest of the four villages, and is small and even more rural than El Recreo. It lies $10 \mathrm{~km}$ to the east of Las Golondrinas. The community recently established a village council, and several villagers were at the verge of establishing a small farmers' palm cooperative when I left the site in December 2000. Diez de Agosto is the only village of the four in my sample that was first populated by way of the road through Las Golondrinas.

Part of my fieldwork focused on trust between members of agricultural cooperatives and the extent to which cooperatives exhibited intra-class trust relationships. In order to understand those networks in a formal organization, I needed first to examine the potential for class-consciousness in informal village networks based on friendship.

Kinship is the basis of most helping relationships beyond the household. Extrafamilial helping relationships, however, also exist. They take the form, for example, of loans, washing someone else's clothes for pay despite limited time, watching a neighbor's house when empty, or buying some small items (for example, batteries) for a neighbor on market day if provided the money.

When people first arrived on the frontier, they helped each other more than they do now - groups of men would work one family's land (clearing trees and planting rice, corn, coffee and cacao) and then move on to do the same on the land of another family. However, once established, a farm family was on its own. Now, at best, adult siblings exchange labor; at worst, they charge each other for a day's work. Stronger political alliances tend to be based on two different issues: whether someone benefits or not from the logging companies operating in the area; and whether or not someone has been part of the local political machine that helped elect a popular local plantation owner. These issues do not seem to affect most of the local people, so their experience of politics revolves around patronage, prestige, and propaganda at election time. Although variation exists based on age, gender and, to a lesser extent, ethnicity, area inhabitants generally maintain their intra-village social relations by visiting on main street on Sunday (market day), seeing each other in church, developing economic patron-client relationships, creating god-parent ties (compadrazgo), and by watching or playing afternoon soccer on a basketball court and soccer at the stadium. Very occasionally it involves visiting one another's homes (which usually involves a request), and visiting at the village store(s).

\section{METHODOLOGY}

I used a snowball sampling technique in the four villages (in November 2000) — La Te, Zapallo, Diez de Agosto, and El Recreo - to elicit local social networks. ${ }^{3}$ An assistant in each village was trained to administer the survey instrument. ${ }^{4}$ A first tier of five people was interviewed, and each was asked the names of three people from the same community to whom they felt the closest. ${ }^{5}$ The first five individuals interviewed in each village were adults selected by the assistant to represent differences in gender, wealth, and location in the village. The degree to which the assistants' choices biased each 
network was not analyzed. The individuals named by tier one became tier two, and each person from tier two provided three names for a third tier of people. This third tier was the last to be interviewed — the individuals named by them were not sought out for an interview. Each individual was asked to provide three names for two reasons. First, each person had to be asked for the same number of names in order to be able to compare network structures across villages. Second, asking for one or two names easily biases the network, while asking for four or more names results in excess data that may mask differences between these small villages. ${ }^{6}$ This technique of three interview tiers produced a sample ranging from 32 in Diez de Agosto to 46 in Zapallo (since some people were named by more than one person in the network; see Appendix 1). ${ }^{7}$ The network was created by using the individuals in the first three tiers and people they named amongst themselves; that is, no one from the fourth tier was included unless they were part of an earlier tier.

Each assistant was responsible for giving the individuals in their sample a wealth code and identifying their religion. Wealth was ranked on a scale from one to four. People coded as "four" typically owned considerable land (usually

Table 2. Number of Individuals in Social Network of Each Village (According to Estimated Level of Wealth and Income).

\begin{tabular}{lrrrrr}
\hline Village & \multicolumn{2}{c}{ No. in Socioeconomic Class in Each Village $(1=$ Low, $4=$ High $)$} & \multirow{2}{*}{ Total } \\
\cline { 2 - 5 } & 1 & 2 & 3 & 4 & \\
\hline La Te & 22 & 10 & 6 & 2 & 40 \\
Zapallo & 3 & 22 & 13 & 3 & 41 \\
El Recreo & 7 & 17 & 8 & 9 & 41 \\
Diez de Agosto & 11 & 8 & 8 & 4 & 31 \\
\hline
\end{tabular}

${ }^{a}$ Diez de Agosto is missing data on one interviewee's class, and Zapallo is missing data on the classes of five interviewees. These were controlled for in the calculations.

with African palm), plus other obvious forms of capital, such as large animal stock or a vehicle. Individuals coded as a "one" were considered to be among the poorest in the community - they were laborers or homemakers not owning their own home. "Two" was a designation for laborers or artisans owning their own home, and "three" for relatively small landowners or the equivalent. After the data were collected, I spent time reviewing the networks and wealth rankings with my assistants. Table 2 provides a break-down of the number of people in each village network according to the class they were assigned to by each of the assistants.

One challenge for the study of social network development is to account for out-migration and changes in networks over time. Some of the people that left the Las Golondrinas area were involved at one time in the social networks of my informants, and their out-migration may have changed the structures of social networks or the kinds of relationships the networks entail. For example, outmigration of a prominent person can cause the network to become less dense, or even to become fragmented. Info i Illation about out-migrants would then allow some reformulation of why the network came to be what it is.

I analyzed the data by using the network visualization program Pajek 0.69 for the graphic depiction of data (Batagelj \& Mrvar, 1996). It allowed me to hand-count mutual relationships between different groups of people based on wealth, family, religion, age, years since arrival, and sex. Mutual relationships are those in which two people interviewed separately name one another. The graphical 
depictions of the networks in this study were created by the Fruchterman-Reingold weighting (2dimensional) feature of Payek 0.69 (see Appendix 2).

In order to code village locations in the dendritic system, I formulated the following sequence in their importance within the regional system. First is La Te, followed respectively by Zapallo, El Recreo, and Diez de Agosto according to the number of roads, number of buses, and number of cars (see Fig. 3; Table 1). ${ }^{8}$

\section{RESULTS AND DISCUSSION}

My analysis attempts to account for the effect of the location of each village in a regional economic system on local social network structure, paying particular attention to micro-level class-based networks of peasants. While several other factors influence social networks - such as time of residence, cultural differences, or gender - the concern here is with the emergence of class and socioeconomic differentiation in small villages of a frontier region.

\section{Social Relationships and Class}

Table 3 depicts the extent to which individuals would be expected to name someone from their own class in each village, as well as how often they actually did name someone from their own class. Except for those in Zapallo, residents of every village relied to a greater extent than would be expected on class as a basis for forming relationships. Perhaps Zapallo's size (compared to El Recreo and Diez de Agosto) and its age (compared to La Te and Diez de Agosto), combined with the fact that it is not a central place, results in the unimportance of class in network formation.

A statistical analysis utilizing every choice by each individual produces a slightly different picture. Only La Te and Diez de Agosto produce significant correlations between class of interviewee and class of person named (correlation $=0.509$;

Table 3. Expected and Observed Non-Mutual Ties within Same Socioeconomic Class, by Village. ${ }^{2}$

\begin{tabular}{lcccc}
\hline Village & $\begin{array}{c}\text { Central Place } \\
\text { Ranking }\end{array}$ & $\begin{array}{c}\text { Expected } \\
\text { Percentage of } \\
\text { Times that Person } \\
\text { in Same Class } \\
\text { would be Named }\end{array}$ & $\begin{array}{c}\text { Observed } \\
\text { Percentage of } \\
\text { Times that Person } \\
\text { in Same Class } \\
\text { was Named }\end{array}$ & $\begin{array}{c}\text { Percentage } \\
\text { Difference }\end{array}$ \\
\hline La Te & 1 & 37 & 59 & 60 \\
Zapallo & 2 & 39 & 34 & -13 \\
El Recreo & 3 & 27 & 36 & 33 \\
Diez de Agosto & 4 & 25 & 35 & 40 \\
\hline
\end{tabular}

\footnotetext{
a "Non-mutual" does not mean that these ties are not reciprocated. It means that the analysis only relies on one person naming another. If that other person named the one who named them, it would merely add one tie to the total and would not be counted as a mutual relationship for the purposes of this table. ${ }^{b}$ Expected ties are the probability of a intra-class tie, based on Table 2 (e.g. $22 / 40 \times 21 / 39+10 / 40 \times$ $9 / 39+6 / 40 \times 5 / 39+2 / 40 \times 1 / 39=0.374$, or $37 \%)$.
}

0.461 respectively). In terms of central place theory, the village of Diez de Agosto - small and isolated - seems an anomaly. However, a closer look at the correlation between an individual's class and the class of the people s/he named shows that classes are clustered within families in Diez de Agosto to a greater extent than in the other three villages. Class ties mimic family ties more in Diez de Agosto. Of course, one of the reasons for this is that Diez de Agosto is the smallest village, so the 
proportion of family ties will be higher compared to the other three villages. Nevertheless, it would be useful for future research to investigate another hypothesis that would account for the similarity of La Te and Diez de Agosto; namely, that members of younger villages (that is, villages whose residents have lived there a short time) tend to have social networks based more on socioeconomic similarities than residents of older villages.

The data analysis so far presented involved on one-way relationships. In other words, I noted when one individual citing someone else as part of his/her network irrespective on whether the person cited actually reciprocated the tie by naming the person who named them. The one-way ties indicate people's preferences, but they do not necessarily indicate the strength of actual relationships. Below I examine the strength of ties by looking at the incidence of mutual relationships.

\section{Mutual Relationships and Class}

Notable in Table 4 is La Te's number of mutual relationships (two people naming each other), and the percentage of these relationships that are based on socioeconomic similarity. In comparison, the more peripheral villages (El Recreo, Diez de Agosto, Zapallo) rely less on wealth-related distinctions in the formation of

Table 4. Mutual Relationships in Four Villages in this Study.

\begin{tabular}{lccc}
\hline Village & $\begin{array}{c}\text { Percentage of People in } \\
\text { at Least one Mutual } \\
\text { Relationship }\end{array}$ & $\begin{array}{c}\text { Percentage of } \\
\text { Relationships that } \\
\text { are Mutual }^{\mathrm{b}}\end{array}$ & $\begin{array}{c}\text { Percentage of Mutual } \\
\text { Relationships that are } \\
\text { Intra-Class }\end{array}$ \\
\hline $\mathrm{La} \mathrm{Te}$ & 93 (of 40) & 32 (of 120) & 60 (of 38) \\
Zapallo & 61 (of 46) & 20 (of 131) & 29 (of 26) \\
El Recreo & 67 (of 41) & 23 (of 118) & 37 (of 27) \\
Diez de Agosto & 65 (of 32) & 20 (of 93) & 27 (of 19) \\
\hline
\end{tabular}

${ }^{a}$ Mutual relationships are those in which two people interviewed in the snowball sample ended up naming each other as one of their three closest ties.

${ }^{b}$ This indicates the percentage of total observed ties between people that were mutual (i.e. percentage of the times any two people were linked together by a mutual tie, out of all the ties that linked any two people).

mutual relationships than does La Te. In La Te, the core village, relationships among people of similar socioeconomic status were twice as common as in the other villages. This finding hints at an interesting principle for the development of frontier inter-personal relationships: villages closer to the core of a frontier tend to be characterized by less diversity in network structure; that is, networks almost exclusively involve intra-class and mutual relationships. Alternatively, villages further away from the core of a frontier will exhibit less uniform and class-based network structures.

As a village becomes more central and turns into a commercial center, people are more likely to focus on fewer and stronger contacts, and may begin to ignore community social responsibilities. How does that transition begin to occur? One mechanism for this transition is the proletarianization of villagers. As seen in Table 2, the majority of people interviewed in the social network sample in La Te are those with the least economic resources. As individuals become more limited in their productive activities due to proletarization (for instance, becoming day wage laborers), they are less able to follow through with social responsibilities that cross class lines, and they may have no other choice than to interact only with people from their own socioeconomic level. 


\section{CONCLUSION}

My objective in this study has been to examine the effect of a village's location in a regional economic system on the nature of social networks among its residents. Based on central place theory, I predicted that the location of villages in a regional system characterized by core-periphery extraction and moderate national integration will affect the nature of each community's social network. Specifically, the question was whether class relationships are dominant in the more central villages of a regional system, while relationships based on interpersonal dynamics — irrespective of class - reign in the more peripheral settings.

My study suggests that as a village becomes a central place and proletarianized, people's relationships become more focused and more oriented towards their own socioeconomic class. Data shows roughly the point in terms of village size and level of economic activity in a central place system at which this occurs. Zapallo, a village of around two hundred households, with another 100 households in its hinterland, is similar in size to La Te, but, unlike La Te, is subject to particularly strong communitybased integrating forces. Enough surpluses can be generated at Zapallo to allow some individuals to spend time in political/bureaucratic activities, which serves as an additional integrating force. By contrast, the dominance of capital/wage-labor relations of production in the central village of $\mathrm{La} \mathrm{Te}$ seems to force villagers to be more exclusive in their friendships, and base these friendships primarily on class similarities.

The implication of this study for regional analysis is that the central place theory needs to be modified to state that one of the reasons central places are different from peripheral ones is because of the development of alienated labor and exclusive class relationships. In societies not based on capitalist relations of production, of course, this may not be true. Ethnohistorical work will be necessary to make such comparisons. The implication of this study for frontier studies is not only that frontiers provide a window into the nature of human social preferences, but also that a synchronic regional analysis of a frontier setting provides a comparative approach to help understand its history. Finally, this research builds on Eric Wolf's (1966, pp. 82-83) argument that only relations which tie a number of people together in multiple relationships based on a common interest (that is, horizontal, polyadic relations) produce lasting coalitions. Horizontal and polyadic relations may not be necessary to create a coalition, but they do appear important for their long-term success.

If living in a more central village (or town) means that people are more likely to have mutual relationships, does this mean it is easier to develop trusting relationships in central places? It is not possible to answer this question from my data alone. Yet, there is the argument by Seligson and Salazar (1979) that peasants are more trusting than urbanites on an interpersonal (rather than political) basis. My data adds to this generalization. Peasants might be more trusting on an interpersonal basis; but, due to a lack of binding socio-economic interests, that trust might not be reciprocated by others. In addition, it is possible that central villages in the countryside afford a greater opportunity for mutual, trusting relationships between peasants due to the development of both specialization and intra-class relationships; that is, the development of a limited universe of likely relationships. The fact that La Te has the highest percentage of mutual relationships suggests that in the more peripheral villages newcomers have a greater tendency to extend their contacts beyond their own status and to rely less on mutual relationships than residents in the more central community. 


\section{NOTES}

1. This is because ethnicity is often based on occupational specialization or on residence. Similarly, class often depends upon occupation. In Ecuador, one determinant of ethnicity is whether you are from the coast or the mountains. If you move from one to the other, the receiving society may eventually accept you as one of "us" costeño or serrano, and the receiving society quickly decides you are now one of "them," regardless of how you feel about it yourself.

2. Zapallo is also peripheral to La Te and Las Golondrinas, while La Te, El Recreo and Diez de Agosto are peripheral only to Las Golondrinas.

3. The sample is a higher percentage of Diez de Agosto's and El Recreo's populations than it is for Zapallo and La Te since the sample is a snowball sample, not a random one.

4. In addition to naming their three closest contacts and their relationship to these three people (i.e. friend, family, or neighbor), informants gave the name of their birthplace/place of origin, the number of years they have resided in their present village, occupation, and whether or not they followed family or friends to the Las Golondrinas area. These variables are not discussed in the current study, although they may have an effect on the role of class in social network development as examined here.

5. "Favor de nombrar las tres personas con quienes mar se lleva usted, afuera de su casa."

6. Since ego-networks are not the object of this study, limiting the response to the names of three trusted individuals has no effect on the degree to which the data to be presented on village network structure is generalizable.

7. The theoretical maximum sample would be $5+15+45=65$.

8. Las Golondrinas, being a much larger town with many different functions, was not an appropriate comparative case.

\section{ACKNOWLEDGMENTS}

The idea to combine social network analysis and regional analysis came from Steve Kowalewski, to whom I am thankful. I am grateful that this manuscript has benefited from the comments of anonymous reviewers, and from comments on earlier drafts by Robert Rhoades, Kavita Pandit, Ted Gragson, Steve Kowalewski, Fausto Sarmiento, and Mika Cohen Jones. Finally, Jeff Johnson provided much appreciated insight into the analysis of network structure. However, any inaccuracies or potential omissions are the responsibility of the author. This research was funded in part by the Sustainable Agriculture and Natural Resource Management Collaborative Research Support Program (USAID Cooperative Agreement \#PCE-A-00-98-00019-00).

\section{REFERENCES}

Appleby, G. (1976). Export monoculture and regional social structure in Puno, Peru. In: C. A. Smith

(Ed.), Regional Analysis, Volume II: Social Systems (pp. 291-307). New York: Academic Press. Batagelj, V., \& Mrvar, A. (1996). Payek 0.69. Ljubljana, Slovenia. http://vladolmf. uni-lj.si/pub/ networks/pajek/

Beck, B. E. F. (1976). Centers and boundaries of regional caste systems; toward a general model. In: C. A. Smith (Ed.), Regional Analysis. Volume II: Social Systems (pp. 255-288). New York: Academic Press. Christaller, W. (1966). Central places in southern Germany. Englewood Cliffs, NJ: PrenticeHall. 
Hall, P. (Ed.) (1966). Von Thünen's isolated state. Oxford: Pergamon Press.

Jones, E. C. (2002). The role of wealth and cultural heterogeneity in the emergence of social networks and agricultural cooperatives in an Ecuadorian colonization zone [Ph.D. dissertation]. Athens, GA: University of Georgia.

Seligson, M. A., \& Salazar, J. M. (1979). Political and interpersonal trust among peasants - a re-evaluation. Rural Sociology, 44(3), 505-524.

Smith, C. A. (Ed.) (1976a). Regional analysis: Volume I, Economic systems. New York: Academic Press.

Smith, C. A. (Ed.) (1976b). Regional analysis: Volume II, Social systems. New York: Academic Press. Smith, C. A. (1976c). Regional economic systems: Linking geographical models and socioeconomic

parameters. In: C. A. Smith (Ed.), Regional Analysis: Volume I, Economic Systems (pp. 3-63).

New York: Academic Press.

Smith, C. A. (1976d). Exchange systems and the spatial distribution of elites: The organization of stratification of agrarian societies. In: C. A. Smith (Ed.), Regional Analysis: Volume II, Social Systems (pp. 309-374). New York: Academic Press.

Smith, E. A. (1988). Risk and uncertainty in the 'original affluent society': Evolutionary ecology of resource-sharing and land tenure. In: T. Ingold, D. Riches \& J. Woodburn (Eds), Hunters and Gatherers I: History, Evolution and Social Change (pp. 222-251). Oxford, UK: Berg.

Thompson, S. I. (1973). Pioneer colonization: A cross-cultural view. Reading, MA: AddisonWesley.

Turner, F. J. (1961). Frontier and section: Selected essays of Frederick Jackson Turner. Englewood Cliffs, NJ: Prentice-Hall.

Wolf, E. R. (1966). Peasants. Englewood Cliffs, NJ: Prentice-Hall.

\section{APPENDIX 1}

Data Used in Construction of Village Networks (Nodelist).

\begin{tabular}{llll}
\hline La Te & Zapallo & El Recreo & Diez de Agosto \\
\hline 1432 & 1678 & 1678 & 1678 \\
2516 & 291011 & 291011 & 29610 \\
3641 & 3121314 & 3121314 & 3111213 \\
4137 & 4151617 & 4131516 & 4141516 \\
56013 & 5181920 & 5171819 & 5171819 \\
661759 & 68121 & 620821 & 692021 \\
762596 & 72218 & 7201922 & 722918 \\
891011 & 818123 & 8231124 & 861012 \\
981012 & 9241320 & 921125 & 92618 \\
108111 & 1031229 & 1026272 & 10122324 \\
11151314 & 11283032 & 112928 & 11122324 \\
1291410 & 12334739 & 1219829 & 1210248 \\
1363811 & 13404125 & 13301231 & 13252026 \\
14131263 & 14262742 & 14603238 & 14272829
\end{tabular}


APPENDIX 1. (Continued)

\begin{tabular}{|c|c|c|c|}
\hline $\mathrm{LaTe}$ & Zapallo & El Recreo & Diez de Agosto \\
\hline 15112764 & 1542743 & 15333435 & 15143031 \\
\hline 16171819 & $1644 \times 34$ & 16363738 & 1651514 \\
\hline 17201621 & 1735836 & 1753940 & 1718532 \\
\hline 18222316 & 1837532 & 1856841 & 18698 \\
\hline 19242565 & 1945182 & $19 \times X X$ & 19152718 \\
\hline 20211716 & 20383234 & 2074243 & 2033634 \\
\hline 21661822 & 2148622 & 21204445 & 216320 \\
\hline 22676818 & 2274950 & 22464748 & 22353637 \\
\hline 23697018 & 23515242 & 2382349 & 2338839 \\
\hline 24192523 & 242125 & $248 \times 50$ & 24101240 \\
\hline 25711924 & 25531320 & 252951 & 25114118 \\
\hline 2672827 & 26145455 & 26105253 & 26251242 \\
\hline 27293130 & 27561557 & 27105455 & 27141943 \\
\hline 28262931 & 2858559 & 2811256 & 28442714 \\
\hline 29722728 & 29231230 & 29121918 & 29254546 \\
\hline 30737227 & 3036028 & 30575818 & $30 \times X X$ \\
\hline 31747529 & 31136119 & 31673859 & 31154714 \\
\hline 32333435 & 3230240 & 32146054 & 32332117 \\
\hline 33323637 & 33126247 & 3334611 & \\
\hline 34323839 & 34521842 & 3461331 & \\
\hline 35323340 & 3516271 & 35615562 & \\
\hline 36377677 & 36175718 & 36163863 & \\
\hline 37363432 & 37186358 & 37163664 & \\
\hline 38343278 & 38151361 & 38654363 & \\
\hline 39793480 & 39106423 & 39246650 & \\
\hline \multirow[t]{7}{*}{40358182} & 40321330 & $40 \times 6038$ & \\
\hline & 41326562 & 41186723 & \\
\hline & 4218366 & & \\
\hline & 43672715 & & \\
\hline & 44521668 & & \\
\hline & $45 \times X X$ & & \\
\hline & $46 \times X X$ & & \\
\hline
\end{tabular}

Note: Leftmost number is the case number (node), the three following numbers are people named by that individual. Only the case numbers were included in the network analysis. Missing data is denoted by an $\mathrm{X}$.

\section{APPENDIX 2}

\section{Visual Presentation of Village Networks}

These graphics were created by the Fruchterman-Reingold weighting (2dimensional) feature of Payek 0.69, which has an oval boundary and depicts the distance (i.e. relative strength of connections) between subgroups based on density within subgroups. using several algorithms. 

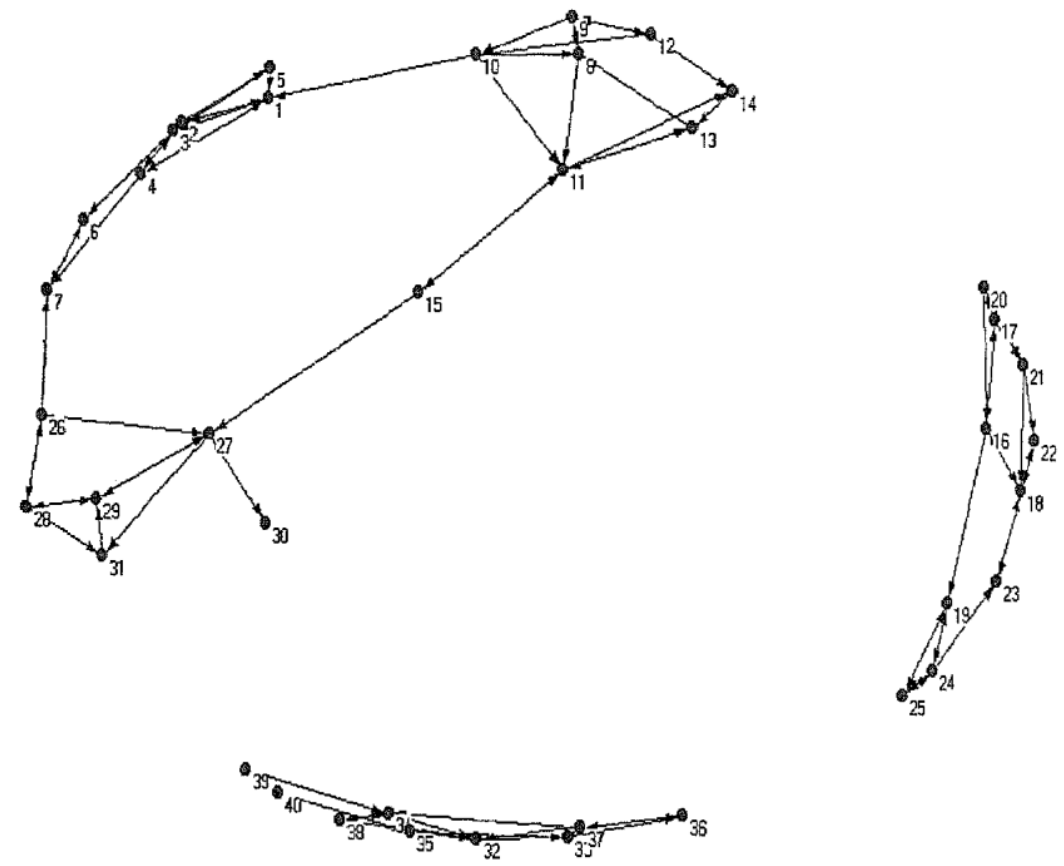

(1) La Te Network. Individuals 1, 8, 15, 16 and 32 were the first people interviewed in the snowball sample.

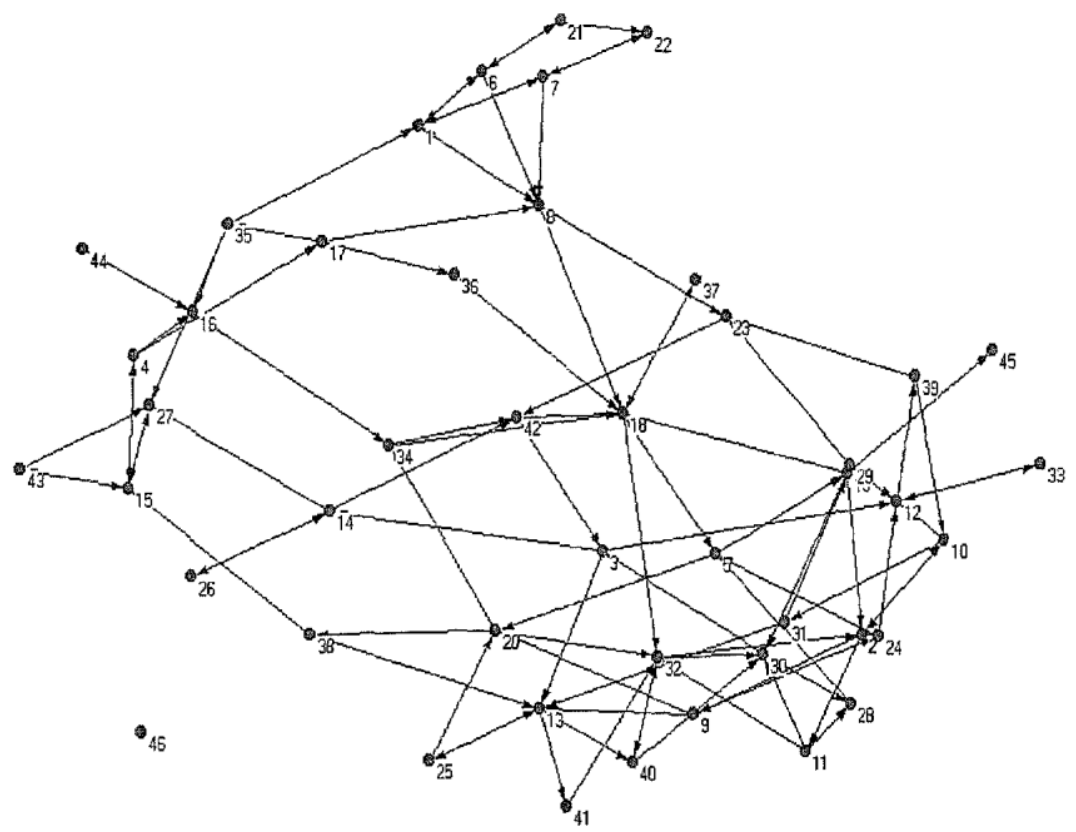

(2) Zapallo Network. Individuals 1-5 were the first people interviewed in the snowball sample. 


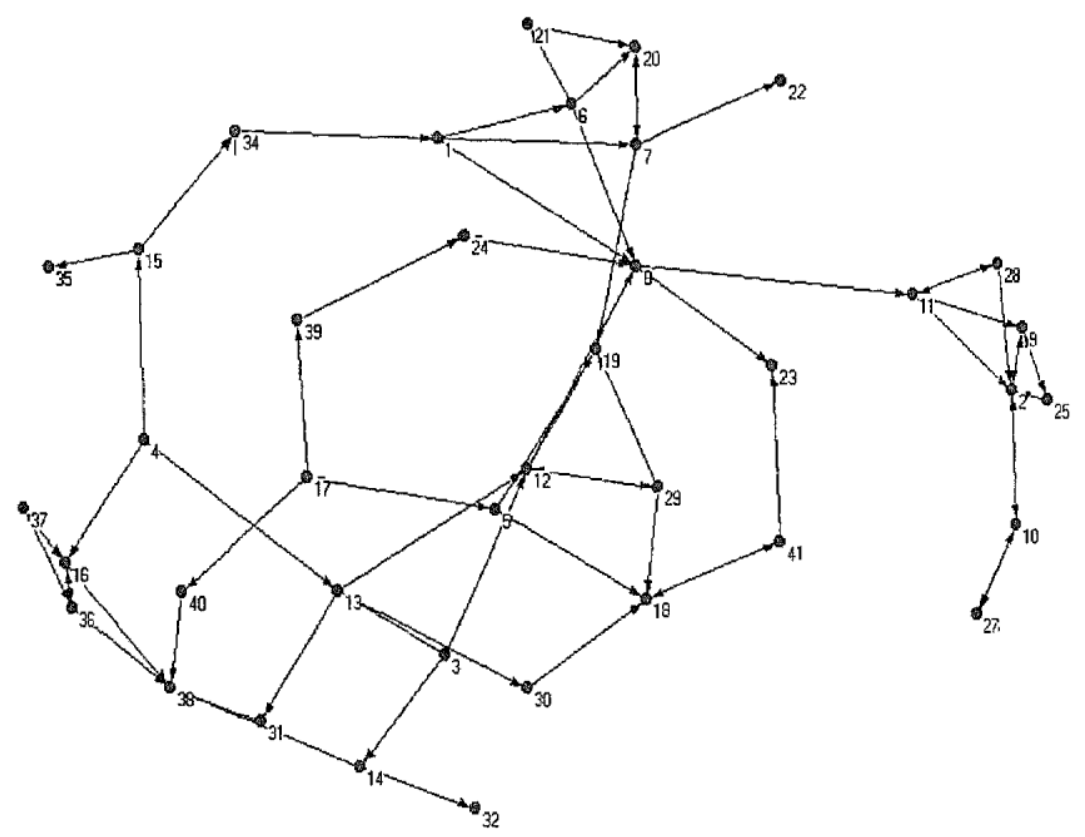

(3) El Recreo Network. Individuals 1-5 were the first people interviewed in the snowball sample.

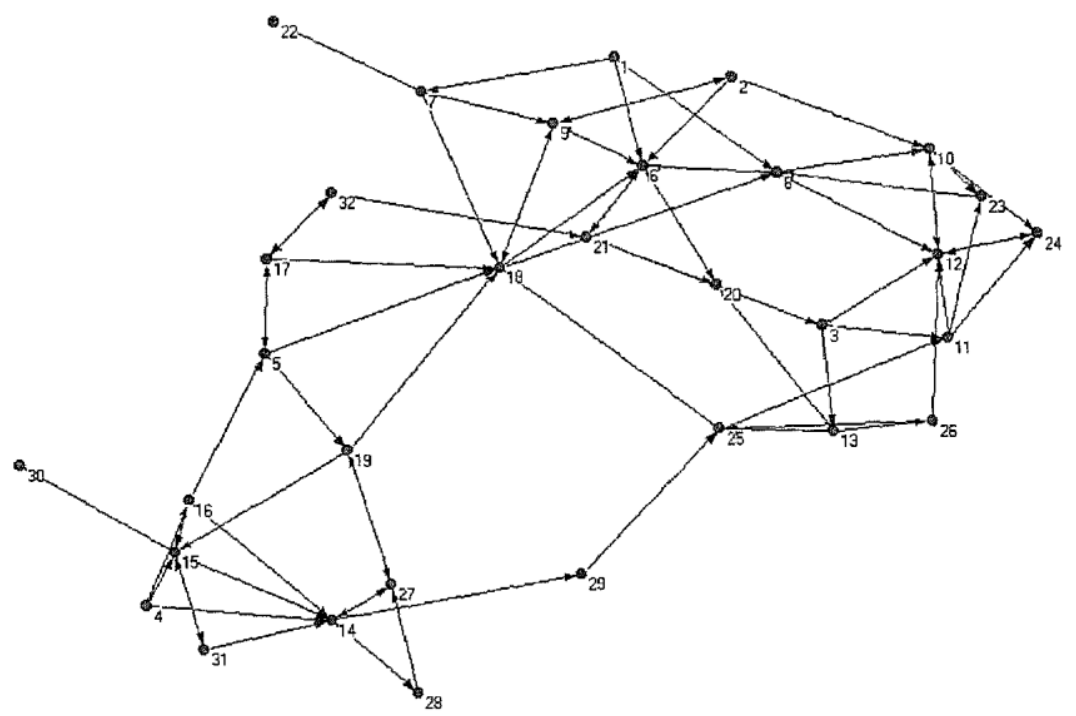

(4) Diez de Agosto Network. Individuals 1-5 were the first people interviewed in the snowball sample. 